\title{
Relationship of the erythrocyte sedimentation rate to viscosity and plasma proteins in rheumatoid arthritis
}

\author{
R. A. CROCKSON AND A. P. CROCKSON \\ Department of Experimental Pathology, University of Birmingham Medical School, Birmingham B15 2TJ
}

The best established laboratory test in the assessment of patients with rheumatoid arthritis is the erythrocyte sedimentation rate (ESR). It is a complex measurement, the major factor being variations in the plasma protein concentrations, but the number and shape of the erythrocytes also contributes substantially. At constant red cell concentration, the relative contributions of the plasma proteins to the ESR are fibrinogen 10, $\alpha 2$ globulins 5, $\gamma$ globulins 2, albumin 1 (Hardwicke and Squire, 1952).

Increase in the concentration of fibrinogen and other macromolecules is associated with increases in both the ESR and the plasma viscosity. The increase in viscosity, which would be liable of itself to slow the sedimentation of the red cells, is more than balanced by the increased rouleaux formation and consequent more rapid rate of sedimentation. Artificial macromolecules, such as dextran and polyvinyl pyrrolidones, have the same effect (Hardwicke and Squire, 1952; Lawrence, 1961). In rheumatic diseases, Shearn, Epstein, Engleman, and Taylor (1963) have shown that the serum viscosity is principally affected by the concentration of the $\gamma$ globulins and of rheumatoid factor.

A number of alternatives to the ESR have been suggested; these include plasma viscosity (Cowan and Harkness, 1947; Eastham and Morgan, 1965), serum and plasma viscosity (Hardwicke and Squire, 1952), and a modified plasma viscosity where allowance is made for the different plasma protein fractions (Lawrence, 1949, 1950).

The present work was undertaken in an attempt to clarify the relationships between the ESR, the serum and plasma viscosity, and the plasma proteins with especial reference to the acute phase proteins.

\section{Methods and material}

All the 62 patients examined had rheumatoid arthritis of varying duration, activity, and severity, and were classified in accordance with the A.R.A. criteria (American Rheumatism Association, 1959) as classical (9), definite (42), or probable (11). There were 22 males and 39 females and the duration of the disease ranged from $2 \mathrm{mths}$ to more than 40 yrs (mean 8.8 yrs).

Venous blood was collected aseptically into sterile glass bottles. Serum and plasma were separated from the cells within $2 \mathrm{hrs}$ of collection and stored at $-20^{\circ} \mathrm{C}$. The ESR was set up within $3 \mathrm{hrs}$ of collection, and the other estimations, with the exception of the gel filtration analysis, were performed within $24 \mathrm{hrs}$ of collection.

\section{Measurements}

ERYTHROCYTE SEDIMENTATION RATE (ESR mm./ 1st hr) by the method of Westergren (1926) modified by Dawson (1960). Readings taken at 1 hour.

HAEMATOCRIT by a standard microcapillary methodo (Strumia, Sample, and Hart, 1954).

PLASMA AND SERUM VISCOSITY by the method of Steel (1948) at $25^{\circ} \mathrm{C}$. using a microviscometer (Hardwicke, 1954). Results expressed relative to $0 \cdot 15 \mathrm{M}$ sodium chloride.

TOTAL AND DIFFERENTIAL SERUM PROTEINS (g./100 ml.) by a modified biuret method (Wolfson, Cohn, Calvary, and Ichiba, 1948) and paper electrophoresis (Hardwicke, 1954).

C-REACTIVE PROTEIN (CRP $\mu \mathrm{g}$./ml.) by a gel diffusion precipitin method (Crockson, 1963).

WAALER-ROSE TITRE (WRT) by a modification of the method of Ball (1950), using sheep cells sensitized with one-third of an agglutinating dose of a potent rabbit antisheep red-cell agglutinating antiserum. In the statistical analysis 'tube number' was used in place of titre.

$\begin{array}{lllllllllll}\text { Tube number } & 1 & 2 & 3 & 4 & 5 & 6 & 7 & 8 & 9\end{array}$ $\begin{array}{llllllllll}\text { Titre } & 16 & 32 & 64 & 128 & 256 & 512 & 1,024 & 2,048 & 4,096\end{array}$ FIBRINOGEN (mg./100 ml.) as thrombin clottable protein estimated by the method of Lempert (Varley, 1962).

gel filtration analysis using Sephadex G-200, column size $85 \times 1.5 \mathrm{~cm}$., eluted with $0.15 \mathrm{M}$ sodium chloride at a flow rate of $10 \mathrm{ml}$./hr. $1 \mathrm{ml}$. serum was used; $2 \mathrm{ml}$. fractions were collected and the protein concentration determined by a modified Folin and Lowry method (Lowry, Rosebrough, Farr, and Randall, 1951). The total protein concentration for each peak expressed as g./100 ml. serum. 


\section{Results}

None of the patients studied had any significant anaemia (haematocrit 36 to 48 per cent. (mean 41.2 per cent.)).

Fig. 1 shows the ranges for nine of the estimations performed on all of the 62 patients, compared with the normal ranges. These results can be divided into groups according to the proportion of the values found above the upper limit of normal. These groups are:

(1) More than 90 per cent. Plasma viscosity 98 per cent. Fibrinogen 94 per cent. CRP 90 per cent.

(2) 50 to 90 per cent. Total $\gamma$ globulins 78 per cent. Total $\propto$ globulins 68 per cent. ESR 66 per cent. Serum viscosity 50 per cent. (3) Less than 50 per cent. Total protein 10 per cent. Correlation coefficients $(r)$ have been calculated between the various tests (Table, opposite). These can be divided into three groups depending on the levels of significance found.

\section{(1) High significance $(\mathrm{P}<0.001)$}

ESR $v$. plasma viscosity, serum viscosity, viscosity difference, CRP.

FIBRINOGEN $v$. viscosity difference, total $\gamma$ globulins.

PLASMA VISCosity $v$. serum viscosity, viscosity difference, total $\alpha$ globulins.

(2) Moderate significance $(\mathrm{P}=0.02-0.01)$

ESR $v$. fibrinogen, total $\gamma$ globulins.
PLASMA VISCosity $v$. fibrinogen, total $\gamma$ globulins, CRP.

SERUM VISCOSITY $v$. total $\gamma$ globulins, WRT.

VISCOSITY DIFFERENCE $v$. total $\alpha$ globulins, CRP.

\section{(3) No significance $(\mathrm{P}>0.05)$}

WRT $v$. ESR, plasma viscosity, fibrinogen, CRP, total $\alpha$ globulins, total $\gamma$ globulins.

TOTAL $\gamma$ GLOBULINS $v$. viscosity difference, total $\alpha$ globulins, CRP.

TOTAL $\alpha$ GLOBULINS $v$. ESR, serum viscosity, fibrinogen, CRP.

SERUM VISCOSITY $v$. viscosity difference, fibrinogen, CRP.

With the possible exception of the correlation of ESR with serum and plasma viscosity in Group 1 there is no significant difference between the calculated values for $r$ within Groups 1 and 2.

Five of the sera were selected to cover the range of serum viscosities encountered and were analysed by gel filtration on Sephadex G-200 and the concentrations of 'macroglobulins' (Peak 1) measured. The results are shown in Fig. 2. Increase in serum viscosity appears to be associated with increased macroglobulin concentration $(r=0.971 ; \mathrm{P}=0.01-0.001)$.

The mean values for nine of the estimations performed have been calculated for the ARA classified groups (Fig. 1). An impression that these represent different biochemical classes is not supported when the differences between the means is compared statistically $(t$ tests; $P>0 \cdot 1)$.

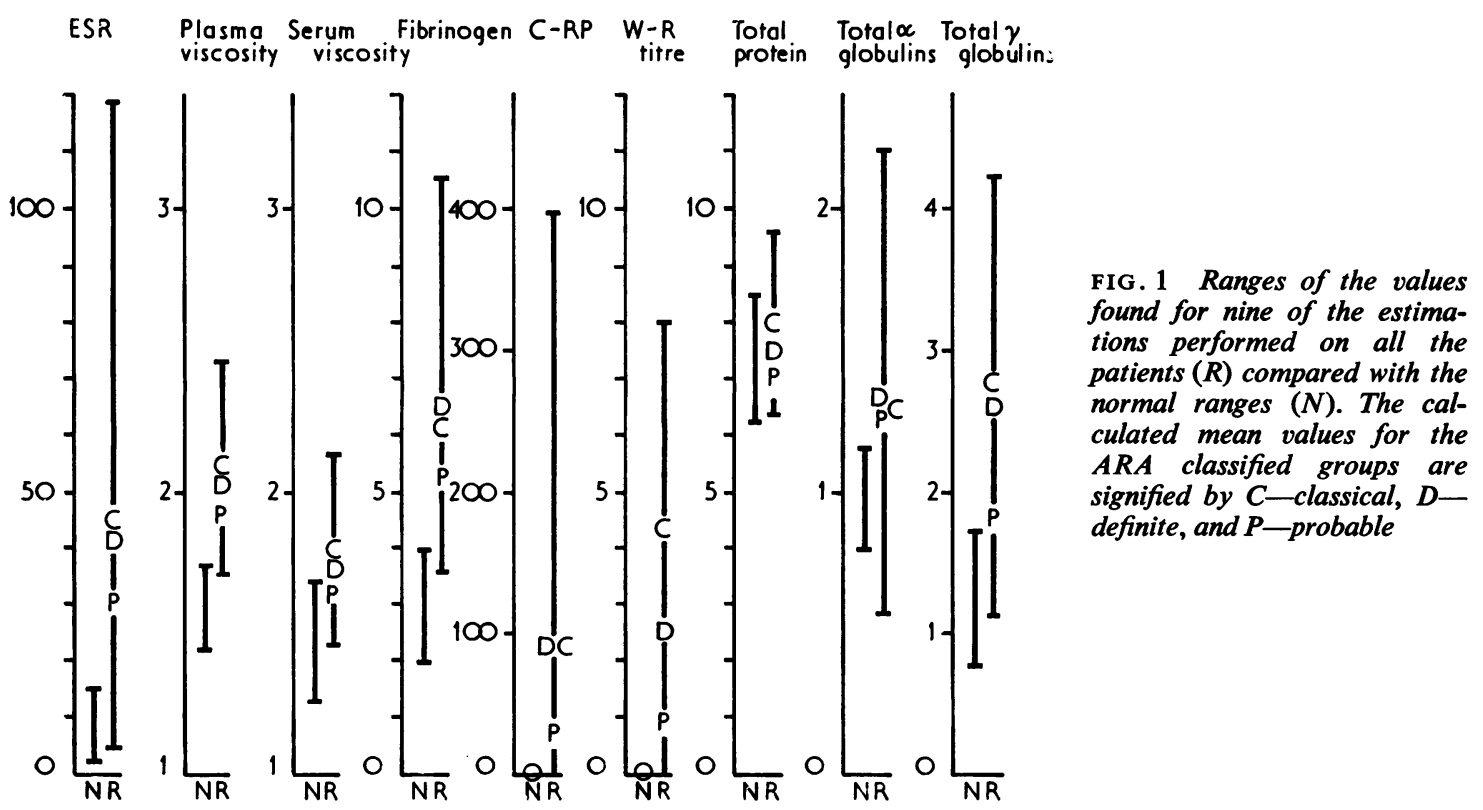


Table Correlation coefficients $(r)$ and probabilities $(P)$

\begin{tabular}{|c|c|c|c|c|c|c|c|c|}
\hline & $\begin{array}{l}\text { Plasma } \\
\text { viscosity }\end{array}$ & $\begin{array}{l}\text { Serum } \\
\text { viscosity }\end{array}$ & $\begin{array}{l}\text { Viscosity } \\
\text { difference }\end{array}$ & Fibrinogen & $\begin{array}{l}\text { Total } \alpha \\
\text { globulins }\end{array}$ & $\begin{array}{l}\text { Total } \gamma \\
\text { globulins }\end{array}$ & $C R P$ & $W R T$ \\
\hline$\overline{\text { ESR }}$ & $\begin{array}{l}0.465^{*} \\
<0.001\end{array}$ & $\begin{array}{l}0.611^{*} \\
<0.001\end{array}$ & $\begin{array}{r}0.56^{*} \\
<0.001\end{array}$ & $\begin{array}{l}0.323^{* *} \\
0.01\end{array}$ & $\begin{array}{l}0.159 \\
>0.1\end{array}$ & $\begin{array}{c}0.343^{* *} \\
0.01-0.001\end{array}$ & $\begin{array}{r}0.55^{*} \\
<0.001\end{array}$ & $\begin{array}{c}0.151 \\
>0.1\end{array}$ \\
\hline Plasma viscosity & $\begin{array}{l}r \\
P\end{array}$ & $\begin{array}{l}0.754^{*} \\
<0.001\end{array}$ & $\begin{array}{l}0.727^{*} \\
<0.001\end{array}$ & $\begin{array}{c}0.385^{* *} \\
0.01-0.001\end{array}$ & $\begin{array}{l}0.742^{*} \\
<0.001\end{array}$ & $\begin{array}{c}0.35^{* *} \\
0.01-0.001\end{array}$ & $\begin{array}{c}0.374^{* *} \\
0.01-0.001\end{array}$ & $\begin{array}{c}0.25 \\
0.1-0.05\end{array}$ \\
\hline Serum viscosity & & $\begin{array}{l}r \\
\mathrm{P}\end{array}$ & $\begin{array}{l}0.091 \\
>0.1\end{array}$ & $\begin{array}{c}0.042 \\
>0.1\end{array}$ & $\begin{aligned} & 0.107 \\
> & 0.1\end{aligned}$ & $\begin{array}{c}0.314^{* * *} \\
0.02-0.01\end{array}$ & $\begin{array}{c}0.231 \\
0.1-0.05\end{array}$ & $\begin{array}{l}0.329 * * \\
0.01\end{array}$ \\
\hline$\overline{\text { Viscosity difference }}$ & & & $\begin{array}{l}r \\
\mathrm{P}\end{array}$ & $\begin{array}{c}0.496^{*} \\
<0.001\end{array}$ & $\begin{array}{c}0.339 * * \\
0.01-0.001\end{array}$ & $\begin{array}{l}0.178 \\
>0.1\end{array}$ & $\begin{array}{l}0.323^{* *} \\
0.01\end{array}$ & $\begin{array}{c}0.033 \\
>0.1\end{array}$ \\
\hline Fibrinogen & & & & $\begin{array}{l}r \\
\mathrm{P}\end{array}$ & $\begin{array}{c}0.383^{* *} \\
0.01-0.001\end{array}$ & $\begin{array}{c}0.413^{*} \\
<0.001\end{array}$ & $\begin{array}{c}0.448^{*} \\
<0.001\end{array}$ & $\begin{array}{l}0.156 \\
>0.1\end{array}$ \\
\hline Total $\alpha$ globulins & & & & & $\begin{array}{l}r \\
\mathbf{P}\end{array}$ & $\begin{array}{c}0.243 \\
0.1-0.05\end{array}$ & $\begin{array}{l}0.209 \\
>0.1\end{array}$ & $\begin{array}{c}0.011 \\
>0.1\end{array}$ \\
\hline Total $\gamma$ globulins & & & & & & $\begin{array}{l}r \\
\mathrm{P}\end{array}$ & $\begin{array}{c}0.274 \\
0.05-0.02\end{array}$ & $\begin{array}{c}0.248 \\
0.1-0.05\end{array}$ \\
\hline$\overline{\text { CRP }}$ & & & & & & & $\begin{array}{l}r \\
P\end{array}$ & $\begin{aligned} & 0.182 \\
> & 0.1\end{aligned}$ \\
\hline
\end{tabular}

* High significance. ** Moderate significance.

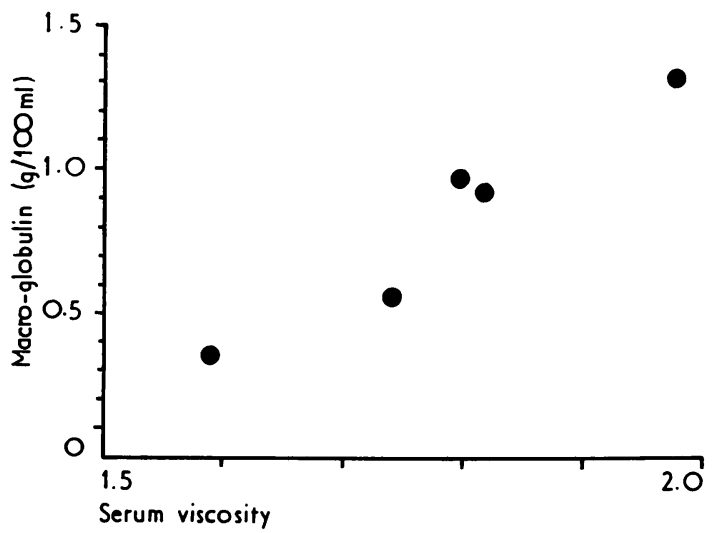

FIG. 2 Plot of macroglobulin concentrations as estimated by gel filtration on Sephadex $\mathrm{F}-200$ against serum viscosity for five selected cases

\section{Discussion}

With the exception of the serum total protein and albumin, all the estimations gave mean values above the upper limit for health and for plasma viscosity, fibrinogen, and CRP at least 90 per cent. of the values were above this limit.

Fibrinogen has been estimated in two different ways: as thrombin clottable protein (fibrinogen) and as the viscosity difference. Although there is good agreement between the two methods $(r=0.496$; $\mathbf{P}<0.001$ ), there are differences between the principles involved and between the results as compared with the other estimations. To avoid confusion, the term fibrinogen will be used when both methods correlatesignificantly; where only one method correlates the descriptive term will be used.

In this study we have found a number of significant correlations; ESR with serum and plasma viscosity, fibrinogen and CRP, also serum viscosity with total $\gamma$ globulins and WRT. These results could be predicted, as both ESR and plasma viscosity are affected by the fibrinogen concentration as is the serum viscosity by the macroglobulin concentration. As the serum viscosity is a component of the plasma viscosity it could influence the ESR.

CRP and fibrinogen are both acute-phase proteins and although they react to the same stimulus at different rates (Crockson, Payne, Ratcliff, and Soothill, 1966), with a continuing stimulus, as in rheumatoid arthritis, they would be expected to and indeed do maintain elevated levels (McConkey, Crockson, and Crockson, 1972). It is unlikely that CRP could directly affect either the ESR or plasma viscosity (molecular weight about 150,000; serum concentration up to $100 \mathrm{mg}$. $/ 100 \mathrm{ml}$.). The correlations of CRP with ESR and plasma viscosity probably represent correlations with the acute-phase proteins in this instance, especially fibrinogen.

A number of the acute-phase proteins are $\alpha$ globulins ( $\alpha 1$-anti trypsin, $\alpha 1$-acid glycoprotein, haptoglobin, ceruloplasmin) and, in health, account for about half of the total $\alpha$ globulins. The balance of the total $\alpha$ globulins is comprised mainly of macroglobulins ( $\alpha$-lipoproteins and $\alpha 2$-macroglobulin) which are not elevated in the acute-phase reaction The acute-phase protein component of the $\alpha$ globulins 
probably accounts for the increase in the total $\alpha$ globulins associated with inflammatory conditions. The correlation between total $\alpha$ globulins and fibrinogen is most probably a relation between acute-phase phenomena, and that with plasma viscosity an indirect one by way of fibrinogen.

The correlations of total $\gamma$ globulins with ESR, serum and plasma viscosity, and thrombin clottable protein are probably explained by two different relationships. Although in health the contribution of the $\gamma$ globulins to the serum viscosity is small (Hardwicke and Squire, 1952), in rheumatoid arthritis, where there is a gross increase in the serum $\gamma$ globulins, their effect is significant (Shearn and others, 1963). This increase in $\gamma$ globulins is associated with an increase in fibrinogen and it may be that these coincident increases account for the correlation of total $\gamma$ globulins with thrombin clottable protein, and that with ESR and plasma viscosity represents both a direct relation by way of the serum viscosity and an indirect effect due to fibrinogen.

We therefore conclude that, in rheumatoid arthritis, the ESR is affected by changes in both the fibrinogen and the total $\gamma$ globulins; that these probably reflect changes in the acute-phase protein and rheumatoid factor respectively. These are independent variables and probably represent different aspects of the disease process and should best be estimated separately. In our studies (McConkey and others, 1972), we have continued to use the ESR as the conventional measurement for comparison, CRP and haptoglobin as acute-phase proteins, and WRT as an estimate of rheumatoid factor.

We are greatly indebted to Dr. A. Paton, Consultant Physician at Dudley Road Hospital, Birmingham, for allowing us access to these patients and for advising us on the clinical aspects of this work. We wish to thank Prof. P. G. H. Gell and Prof. J. Hardwicke for their advice and interest.

\section{References}

American Rheumatism Association (1959) Ann. rheum. Dis., 18, 49 (Diagnostic criteria for rheumatoid arthritis)

BALL, J. (1950) Lancet, 2, 520 (Serum factors in rheumatoid arthritis agglutinating sensitized sheep cells)

CoWAN, I. C., AND HARKNESS, J. (1947) Brit. med. J., 2, 686 (The plasma viscosity in rheumatic disease)

Crockson, R. A. (1963) J. clin. Path., 16, 287 (A gel diffusion precipitin method for the estimation of C-reactive protein)

- PAYne, C. J., Ratcliff, A. P., AND Soothill, J. F. (1966) Clin. chim. acta, 14, 435 (Time sequence of acute phase reactive proteins following surgical trauma)

DAwson, J. B. (1960) Brit. med.J., 1, 1697 (The ESR in a new dress)

Eastham, R. D., AND Morgan, E. H. (1965) J. med. Lab. Technol., 22, 70 (Plasma viscosity in clinical laboratory practice)

HARDWICKE (1954) Biochem. J., 57, 166 (The estimation of serum proteins by electrophoresis on filter paper)

- AND SQuiRE, J. R. (1952) Clin. Sci., 11, 333 (The basis of the erythrocyte sedimentation rate)

LaWrence, J. S. (1949) Ann. rheum. Dis., 8, 209 (Plasma viscosity)

(1950) J. clin. Path., 3, 332 (The plasma viscosity)

- (1961) 'Assessment of the Activity of Disease', p. 34. Lewis, London

Lowry, O. H., Rosebrough, N. J., Farr, A. L., and Randall, R. J. (1951) J. biol. Chem., 193, 265 (Protein measurement with the Folin phenol reagent)

McConkey, B., Crockson, R. A., AND Crockson, A. P. (1972) Quart. J. Med., NS 41, 115 (The assessment of rheumatoid arthritis)

Shearn, M. A., Epstein, W. V., Engleman, E. P., ANd Taylor, W. F. (1963) J. Lab. clin. Med., 61, 677 (Relationship of serum proteins and rheumatoid factor to serum viscosity in rheumatic diseases)

Steel, A. E. (1948) Bull. Inst. med. Lab. Technol., 14, 78 (A micro method for determination of viscosity of plasma)

Strumia, M. M., Sample, A. B., And Hart, E. D. (1954) Amer. J. clin. Path., 24, 1016 (An improved micro hematocrit method)

VARLEY, H. (1962) 'Practical Clinical Biochemistry', 3rd ed., p. 191. Heineman, London

WestergRen, A. (1921) Acta med. scand., 54, 247 (Studies of the suspension stability of the blood in pulmonary tuberculosis)

Wolfson, W. Q., Cohn, C., Calvary, E., and Ichiba, F. (1948) Amer. J. clin. Path., 18, 723 (Studies in serum proteins) 